\title{
DA GEOGRAFIA E DA HISTORIA OU UM EXEMPLO DE INTERDISCIPLINARIDADE
}

"Nas minhas hesitações entre a História, onde a Idade Média me atraía especialmente, e a Geografia, o que definitivamente me encaminhou para esta foi a leitura de VIDAL DE LA BLACHE (...). Os Principios de Geografia Humana, com o seu constante apelo à observação e ao passado, consolidaram as duas tendências do meu espíriton.

ORLANDO RIBEIRO - Ensaios, p. 17

A recente reedição de Portugal, o Mediterrâneo e o Atlantico e Mediterráneo. Ambiente e Tradição, permitiu aos leitores interessados disporem de duas obras fundamentais de ORLANDo RIBEIRo que ilustram claramente as tendências que nortearam a sua vida científica. Partindo da análise das condições físicas que servem de cenário e condicionam as realizações humanas, as marcas do homem na paisagem são analisadas e interpretadas numa harmoniosa conjugação da Geografia com a História. A terra e o homem e as suas interacções são os temas à volta dos quais se desenvolve a construção de grandes frescos que permitem uma visão das áreas tratadas e suscitam a sua compreensão.

$O$ apelo da História e, em particular, da Idade Média, a que se aliou a controvérsia sobre os factores determinantes da formação de Portugal, estimulou o desenvolvimento de estudos no sentido de contribuir para o esclarecimento de tão importante tema. Os ensaios produzidos foram publicados, ora constituindo capitulos de obras como em Portugal, o Mediterrâneo e o Atlântico e na Geografia de Portugal, ora em artigos dispersos em várias publicações.

A dispersão e, nalguns casos, a dificuldade de encontrar estes importantes ensaios, tornou necessário reuni-los num único volume, facilitando a sua maior divulgação. Assim, em 1987, foi publicado o volume Formação de Portugal o qual, reeditando textos já publicados, inclui também um inédito.

A obra encontra-se dividida em duas partes, sendo a primeira dedicada a análise de aspectos de conjunto e a segunda a aspectos regionais. A primeira parte inclui como núcleo fundamental o ensaio "Formação de Portugaln, já publicado no Dicionário de História de Portugal (dir. JOEL SERRÃo), onde são analisados os antecedentes e os factores que explicam o aparecimento de um território politicamente autónomo no Ocidente da Península Ibérica. E feita uma apreciação crítica das teses dos vários historiadores que se debruçaram sobre o tema. Ao traçar - quadro físico do território português, mostra que este não pode ser a base explicativa que alguns tentaram alegar. $\mathrm{E}$ a História e não a terra que fornece a fundamentação que permite explicar a origem de Portugal.

Os povos e as culturas anteriores à Reconquista são objecto de análise na medida em que "E lícito procurar, para um Estado medieval 
e uma nação que se vazou, em grande parte, nos seus moldes, as suas raízes humanas mais remotas em todos os elementos de civilização..." (p. 25).

As várias fases da Reconquista, a génese de Portugal, a importância das várias formas de organização do país levadas a cabo quer pelas ordens religiosas, quer pela nobreza, ou através de outros processos de cedência dos direitos de domínio da terra, como os concelhos, a definição da fronteira, são outros aspectos abordados ao longo deste ensaio fundamental para geógrafos e historiadores. Os outros três ensaios desta primeira parte, um dos quais inédito, desenvolvem temas tratados no primeiro texto.

A segunda parte, integra dois artigos: "Portugal e o Algarve: singularidade de um nome de província» e «Reflexões sobre a Estremadura: significado e origem do nome». Alguns artigos, quer da primeira, quer da segunda parte da obra, são ilustrados com cartografia que clarifica a importância espacial dos fenómenos analisados.

Se a formação do Estado português é um importante momento da nossa história, um outro há que mereceu igualmente um amplo interesse na obra científica de ORLANDo RIBEIRo: a Expansão Portuguesa e as consequências da diáspora lusa pelas "sete partidas do mundo".

O título Aspectos e Problemas da Expansão Portuguesa, publicado em 1962, reuniu em volume alguns ensaios dispersos por várias publicações a par com alguns inéditos. Há muito esgotado, impunha-se a sua inclusão no plano das obras a publicar ou a reeditar. A sua organização foi repensada, acrescentando-se-ihe muito material entretanto publicado ou ainda inédito. Os temas iniciais foram enriquecidos com a inclusão de estudos sobre as colónias africanas e o Brasil.

A divulgação desta importante obra que se prevê para breve, será de uma oportunidade única, quando se comemoram os 500 anos dos Descobrimentos Portugueses. A sua publicação justifica-se pela necessidade de perspectivar os acontecimentos e de ajuizar das consequências que eles tiveram para os povos e áreas do mundo que envolveram. Conhecer o passado para melhor compreender $o$ presente e preparar o futuro, eis um dos muitos ensinamentos que temos o privilégio de poder colher nas obras de ORLANDo RIBEIRo.

Julia Galego

\section{OBRAS CITADAS NO TEXTO}

RIBEIRo, ORLANDo-Aspectos e Problemas da Expansāo Portuguesa, Lisboa, Junta de Investigaçōes do Ultramar, 1962.

- Ensaios de Geografia Humana e Regional, Lisboa, Sá da Costa, 1970. A Formação de Portugal, Lisboa, Instituto de Cultura e Língua Portuguesa, 1987.

- Geografía de España y Portugal, Tomo V, Portugal, Barcelona, 1954. Mediterrâneo, Ambiente e Tradição, 2." ed., Lisboa, Fundação Calouste Gulbenkian, 1987.

Portugal, o Mediterrâneo e o Atlântico, 4." ed., Lisboa, Sá da Costa, 1986. 